\title{
Effective Ways to Implement Japanese Teaching in Colleges and Universities under the New Situation
}

\author{
Zhang Hui, Xiao Liangdong \\ Jingdezhen Ceramic University
}

Key words: Second foreign language; Japanese teaching; teaching approach

\begin{abstract}
At present, many colleges and universities in the elective courses are arranged in a second foreign language, such as Japanese, Chinese and so on, but most of the school's second foreign language teaching there are short teaching time, teaching materials are not uniform, low degree of attention, This paper takes the teaching of Japanese as an example and makes a simple inquiry into the teaching approach of the second foreign language, which can only provide reference for the teaching work of relevant teachers in colleges and universities.
\end{abstract}

With the continuous advancement of globalization, many schools have carried out the second foreign language teaching, hoping to cultivate more in line with the current situation of multilingual talent, due to Japan and Japan, China and Japan economic exchanges between Therefore, Japanese is the common language in the second foreign language teaching in Chinese universities. This paper mainly discusses the common and effective ways of Japanese teaching in Japan.

\section{To fully stimulate students' interest in learning}

1.1 The importance of stimulating students' interest in learning. Interest is the main driving force for students to learn Japanese, only to fully stimulate students' interest in learning, to be able to create their curiosity. For a long time, teachers are using the indoctrination of teaching methods, teaching methods are very simple, very boring classroom atmosphere, coupled with language learning itself is a gradual process, there will be no obvious short-term teaching effect, Students experience less than a sense of achievement in learning, students will learn Japanese as a spiritual burden, to some extent affected the efficiency of Japanese classroom teaching. Therefore, Japanese teachers in colleges and universities should be able to actively innovate the teaching methods in the practical teaching, and stimulate students' interest in learning through diversified teaching methods, so as to make the passive learning become the active learning. Only in this way, Japanese teachingcan be really improved effectively.

1.2 How to Stimulate Students' Interest in Learning. In order to stimulate students 'interest in Japanese language learning, Japanese teachers in universities must actively change the teaching concept and innovate teaching methods to attract students' interest in learning. In the classroom, we should be able to explain the Japanese knowledge in everyday life, so that we can further the distance between Japanese teaching and students. In class, we should be able to understand the students' ideas about Japanese learning through the communication between teachers and students. , As a basis for teaching methods to make certain improvements, making Japanese teaching more in line with the cognitive situation of students, thus stimulating the enthusiasm of students.

The use of multimedia teaching is to stimulate students interest in learning an effective means of teachers in their daily teaching to be able to fully use the multimedia network to collect some of the more interesting games, tongue twisters or Japanese songs, or use a variety of tools to design a certain teaching situation, To stimulate the students' senses, to stimulate their interest in students. Such as through the multimedia textbooks will be static in the context of dialogue text into a sound, the image of the form, so that students more vivid and realistic into such an environment, to mobilize the students' visual, hearing and other senses to stimulate interest in their new language learning, Inspire students to learn thinking. For example, to guide students to learn to sing some of the relatively familiar Japanese songs, such as the Japanese version of "sweet honey", the Japanese 
song learning process, the teacher should explain the meaning of the lyrics, let the students learn some words in the song learning . In addition, the Japanese anime by many young students, teachers in Japanese learning can download some of the higher acceptance of animation or more classic Japanese film clips in the teaching gap to play, adjust some classroom atmosphere, to fully mobilize the students interest in learning .

In order to stimulate students 'interest in Japanese learning, teachers should be able to change their teaching methods, combine theory with practice, and mobilize students' interest through comprehensive practice. While attaching importance to basic knowledge teaching, we should strengthen the training of students 'oral English and improve the students' practical ability in Japanese. Extensive extracurricular Japanese display is an important form of communicative training. It is an effective means to train students' Japanese practical ability, active students' thinking and stimulate students' interest in learning. Students will be able to participate in the Japanese language actively by creating an excellent language environment for the students through the extracurricular Japanese language display activities. For example, students can take part in the "Japanese Corner" Through the Japanese free to express their own words, can stimulate students interest in Japanese learning.

\section{To improve teaching methods}

2.1 Group cooperative learning. Group cooperative learning is a very common teaching method in Japanese teaching, which can effectively improve students' classroom participation. Teachers should follow the basic principles of "heterogeneity within groups, homogeneity among groups" when classifying study groups. Students should be able to grasp the basic knowledge of Japanese, the level of Japanese basic knowledge, the ability to learn Japanese and so on according to the students' interests, Factors reasonable mix of group members there are some differences, but in general the same learning objectives, but also reflects the Japanese language education fairness, equality. The number of cooperative learning group should not be too much, 4 to 6 people the best, the number of members of the team is not clear enough, the students can not fully demonstrate their talents, the number is too small to reflect the cooperative learning team spirit. In order to facilitate mutual understanding between the group members, the study group should be relatively stable, but also to enhance the team cohesion between students, but in order to prevent students from interdependence, effectively stimulate the vitality of the study group to expand the scope of students' Adjust the changes in a timely manner. Cooperative learning in the process of team members to help each other, correct inaccurate pronunciation, through this teaching method can make all the students are able to actively participate in teaching activities.

2.2 Listening and Speaking Training. Listening and Speaking Training is an important means of language learning. Through listening, students can receive many kinds of information, get a sense of language, learn the correct way to express personal thoughts from reading from radio, TV, and others. So that teachers must pay attention to listening and speaking training, encourage students to participate in language practice, the only way to improve the practical application of language ability. Listening and speaking is always one, only continuous listening training, absorb a lot of language information, students in the process of oral expression will not rigidly adhere to the sentence training, will learn to select the language based on language environment and language rules, And ultimately achieve the goal of free expression. The first stage of Japanese learning, teachers should be able to through radio, television and other forms to enable students to listen to as much as possible training, and then encourage students to communicate more open, fluent in Japanese oral expression of the basic routines for language activities to lay a good foundation. After the students 'oral English level has been improved, the students' language skills will be practiced by retelling the passage of the passage. Spoken language teaching should be carried out in stages, step by step, from shallow to deep. Pre-teaching teachers need to strengthen guidance, students gradually formed when the free expression of consciousness, as much as possible for students to create use of Japanese for oral expression opportunities, such as group debate, scenarios, speech competitions, etc., these are The effective measures to train the Japanese students' ability of expression are very 
beneficial to the Japanese students studying in the universities.

2.3 Promote the national culture cognitive method. In addition, the Chinese culture and Japanese culture there is a big difference, under the influence of this difference, students often appear in various language errors, such as language errors, the use of occasions is not appropriate and so on. Therefore, language learning is not only the study of vocabulary and grammar, but also the study of national culture, customs, and historical background. Only in this way can we avoid language errors caused by cultural differences. Japanese language teaching must pay attention to the infiltration of Japanese culture, especially the students' language ability to a certain level, the cultural barriers will gradually highlight the language errors can easily lead to a variety of friction, which is very detrimental to student communication. Therefore, Japanese teaching must pay attention to Japan's history and culture, customs and habits of introduction, to narrow this cultural differences. In addition, through the implementation of a number of practical activities related to Japanese culture can also help students understand the foreign culture, which is also very helpful for Japanese teaching.

\section{Conclusion:}

In order to improve the interest of Japanese teaching in the university, teachers should analyze the problems existing in the current Japanese teaching in detail. Combining with the thinking and cognitive characteristics of the students in higher education stage, the teachers should constantly improve the innovative teaching methods, The teaching methods to stimulate students' interest in learning, and guide students to actively and actively participate in the Japanese classroom teaching process, so as to promote students to improve the efficiency of Japanese learning.

\section{Acknowledgement}

This paper is the result of the teaching reform and research project of Jingdezhen Ceramic University in 2015 (the subject self-organizing fund number 212050-007). The results of the research on the teaching mode of "Japanese translation" micro-teaching + flip classroom "

\section{References:}

[1] Zhao Shuwen. University of Japanese teaching public comment [J]. Science and Technology Information. 2013 (23)

[2]Chi Zhuobei. The Current Situation and Problems of Japanese Elective Courses in Universities. Technology Information. 2013 (15)

[3] Jin Caixia Vocational Teaching Japanese Beginners - Qingdao Vocational and Technical College [J] Henan Science and Technology 2012 (10).

[4]Shang Xueyan. On the Japanese as a second foreign language teaching [J]. Decision-making exploration (second half) 2013 (02) 